\title{
Effect of Liquidity and Capital on Risk-Adjusted Efficiency of Banks in Emerging Economies: Evidence From Ghana
}

\author{
Samuel Antwi \\ University of Professional Studies \\ Mohammed Issah \\ University of Professional Studies \\ David Sarpong \\ Accra Technical University
}

\begin{abstract}
The performance of the banking industry plays a crucial role in achieving sound and accelerated economic growth. This study aims to estimate the risk-adjusted cost and profit efficiencies of banks in Ghana, to assess the effect of liquidity and capital on the estimated risk-adjusted efficiencies. The study employs the parametric (SFA) frontier over the period 2009 - 2018. The results reveal that increase in bank liquidity results in an increase in both risk-adjusted cost efficiency and risk-adjusted profit efficiency. High levels of bank capital are also associated with increases in both risk-adjusted cost efficiency and risk-adjusted profit efficiency.
\end{abstract}

Keywords: liquidity, capital, efficiency, banks, Ghana

\section{INTRODUCTION}

The efficiency of the banking industry plays a crucial role in achieving sound and accelerated economic growth since it is a critical part of the financial system in every economy (Kumar and Gulati 2008). The measurement of bank efficiency plays a pivotal role in the accurate assessment of the performance of individual banks and the industry as a whole, whiles providing information concerning the overall stability of the entire financial system. Inefficiencies in the banking industry can cause a banking crisis and impede economic growth since they are the main financial intermediation channels. Ensuring efficiency in the banking system and financial markets is the main preoccupation of every monetary and financial environment. According to (Berger et al, 1993), for banks, efficiency implies improved profitability, greater amounts of funds channelled through the system, better rates and service quality for consumers, and greater safety in terms of sufficient capital buffers in absorbing risk

The Ghanaian financial system has grown substantially during the past decade, with total assets at the close of 2019 reaching fifty-four (54) per cent of GDP for the same period, (IMF, 2019). However, internal controls and risk management practices of financial institutions have not always kept up with the industry's growth, as evidenced by a steady increase in nonperforming loans over the years and, more recently, several 
high-profile banking failures (BOG, 2018). While reforms have been stepped up in response, it has also become clear that fragilities extend well beyond the banking sector, with specialized deposit-taking institutions and fund managers also facing distress, (IMF, 2019).

The Ghanaian banking sector has undergone several regulatory restructuring and transformations over the last decade, as part of the country's restructuring and transformation program to enable the sector to offer services efficiently within the globalized financial system. Major regulatory reform is the directive requiring universal banks operating in Ghana to increase their minimum stated capital to GHS400 million by the end of 2018 (BOG, 2019). The minimum stated capital was initially increased to GHS60 million in 2007 and then in 2013 it was increased to GHS100 million. There was also the introduction of the Universal banking license, which allows banking to provide various forms of banking services. As part of measures to further strengthen risk management across the industry, the Bank of Ghana (BOG) issued the Capital Requirement Directive, the rule book for Basel II\&III compliance, effective January 2018. The implementation is expected to align the level of risk banks choose to carry with the amount of capital they hold, which is particularly important to protect investors' and customers' funds as banks take steps to increase their capital in line with the new minimum capital requirement.

Efficiency is linked to the possibility of avoiding wasting by producing as much output as the utilization of inputs allow it (output-oriented measure), or by using fewer inputs that the production objective plans it (input-oriented measure). Cost efficiency measures the change in a bank's variable cost adjusted for random error, relative to the estimated cost needed to produce an output bundle as efficiently as the best-practice bank in a sample facing the same exogenous variables, which include variable input prices, variable output quantities and fixed net puts (inputs and outputs) (Kwan and Eisenbeis, 1997; Berger and DeYoung, 1997). Cost inefficiency arises due to technical inefficiency, which results in the use of excess or a sub-optimal mix of inputs given input prices and output quantities (Williams, 2004). Profit efficiency shows how well a bank is predicted to perform in terms of profit relative to other banks in the same period for producing the same set of outputs. Most empirical studies on profit efficiency report efficiency levels that are lower than cost efficiency levels (Maudos et al., 2002).

Risk can be explained as the variability of expected returns or the probability of an adverse outcome. According to the Basel Committee on Banking Supervision (2000:1), credit risk can be defined as "the potential that a bank borrower or counterparty will fail to meet its obligation following agreed terms."

Many studies have established a relationship between bank efficiency and credit risk, (DeYoung, 1997; Goodhart et al, 2004; Allen and Gale, 2004; Boyd and De Nicolo; 2005, Podpiera and Weill 2008; Mamatzakis and Koutsomanoli-Filippaki, 2009; Fiordelisi et al 2011). Following the 'bad luck hypothesis', an increase in the default risk of a bank causes a decrease in its efficiency. According to DeYoung (1997), a rise in a bank's risk which is explained as an increase in the bank's probability of default will cause managers to operate less efficiently. This is because managers who are exposed to soaring default risk will need to put in additional precautionary measures and also incur additional risk monitoring costs to preserve the asset quality of the bank. It will also cause the bank managers to shift their attention from providing solutions from the day to day operational problems and also from pursuing efficiency improving strategies to preventing further deterioration of the bank's financial position. In the extreme case where a bank is in a dangerous financial position, close to or below the threshold of default, it will be faced with high costs to defend its safety and soundness records to supervisors and market participants. The higher cost incurred as a result of an increase in bank default risk will trigger an increase in bank inefficiency.

Theoretically, the level of a bank's capital has a relationship with its efficiency. A positive relationship may derive from a reduced moral hazard between shareholders and debenture holders. Because shareholders have limited liability, low capital ratios increase their incentives to take on excessive risk without taking commensurate measures to improve asset quality and thereby resulting in declining efficiency scores. This behaviour is reinforced by explicit or implicit government guarantees of customer deposits. A higher capital ratio will therefore minimize risk shifting and increase the motivation of shareholders to increase efficiency and control risk. When banks hold more capital, they are more careful in terms of risk behaviour, which can be translated into higher efficiency scores. More capitalized banks are more efficient because they have higher creditworthiness, engage in more prudent lending and borrow 
less, which reduces their cost and increase their efficiency. Higher capitalization also lessens agency problems between managers and owners. Therefore, owners will have a greater incentive to monitor management performance and ensure that the bank is efficient. Empirically, several studies have established an association between bank capital and efficiency. For instance, (Pasiouras, 2008; Banker et al, 2010; Barth et al, 2013) show a positive association between bank capital and efficiency. It is also identified that banks that hold more capital buffers as retained earnings are more efficient, (Carvallo and Kasman, 2005; Ariff and Luc, 2008).

Ensuring adequate liquidity is essential in banking operations because of the financial intermediation role of banks (transforming short term deposits to long term loans). This intermediation role of banks exposes them to an inherent liquidity risk, which can have dire consequences on the banks' earnings and solvency (Berger and Bouwman, 2009). Banks in many economies have been required by regulators to maintain some amount of liquidity to be used primarily as insurance for depositors and also to settle interbank indebtedness. The Banking Act of Ghana requires banks to maintain nine per cent of their deposits as a primary reserve in an account with BOG. Liquidity is expected to influence bank efficiency as banks holding more liquid assets benefit from a superior perception in funding markets, reducing their financing costs and increasing profitability, thereby improving their output/input and profit/input ratios. Higher liquid assets reduce the illiquidity and financing cost of banks. Liquid banks are expected to be more efficient in the sense that, all other things being equal, liquid banks can produce more output in the form of loans and other interest-earning assets as opposed to illiquid banks which does not have the liquidity to meet the demands such output. Several studies have found a positive relationship between liquidity and efficiency, (McKillop et al, 2002, Gorton and Huang, 2002; Staikouras and Wood, 2003). However, empirical literature suggests a mixed relationship between liquidity and efficiency ( Altunbas et al., 2007; Khalib et al.,2016; Sarmiento and Galan, 2017).

Even though some literature exists on the effects of liquidity and capital on bank efficiency, such studies failed to incorporate risk in the efficient frontier. These studies did not take into account the credit risk associated with the banks' operations. However, according to (Mester, 1996; Altunbas et al, 2000; Altunbas et al, 2001; Maudos et al 2002; Pastor and Serrano, 2005), the failure to adequately account for risk in the estimation of efficiency can have a significant impact on the relative efficiency scores. These studies assert that unless the risk is controlled for, the level of a bank's inefficiency can be miscalculated and for that matter, the credit risk characteristics of banks need to be incorporated in the underlying industry cost and profit efficient frontier.

The central aim of this study, therefore, is to estimate the parametric risk-adjusted cost and profit efficiencies of banks in Ghana, to assess the effect of liquidity and capital on the estimated risk-adjusted efficiencies. Policy implications and recommendations will be provided. The contributions and novelty of the study are discussed in due course in the upcoming sections.

\section{METHODOLOGY}

\section{Research Design}

The quantitative research approach was adopted in this study. A panel data methodology, specifically balanced panel data, was adopted in this study. The panel data methodology is also adopted because the study comprises repeated observations on the same cross-section of units over time (Wooldridge, 2012). Moreover, the panel data methodology provides more information and degrees of freedom, and reduced collinearity among the explanatory variables (Baltagi, 2008). The fixed-effect model and the random effect model are the estimation techniques applied, and the Hausman test was used to choose between the two estimation techniques. Other diagnostic tests were run to investigate heteroscedasticity, multicollinearity and autocorrelation problems and to account for them should they exist.

\section{Sources of Data and Sampling}

The population for the research comprises all the twenty-three (23) universal banks operating in Ghana. Since not all these banks were in existence for the entire study period, the seventeen (17) banks which 
operated continuously in the Ghanaian banking industry for the entire study period were used for the research. Data covering the years 2009-2018 were extracted from the annual financial reports of the banks under consideration. Data was also sourced from the banking supervision department of the BOG and crossvalidated with similar data from the banks' annual financial reports

\section{The Stochastic EconFometric Frontier Model and Inefficiency Measures}

The stochastic econometric frontier model postulates that a bank's observed cost will deviate from the cost frontier because of random noise, $V_{i t}$ and possible inefficiency, $U_{i t}$. That is, for $\mathrm{N}$ banks in the sample,

$\operatorname{lnT} C_{i t}=\ln f\left(P_{i t} Q_{i t} R_{i t} ; \beta\right)+\left(V_{i t}+U_{i t}\right) \ldots \ldots \ldots \ldots i=1 \ldots \ldots N$,

where: $T C_{i t}$ represents the observed total cost of the ith firm in the ith period; $P_{i t}$ and $Q_{i t}$ are the vectors of input prices and output quantities; $R_{i, t}$ is a variable characterizing the asset quality of the bank; $\beta$ denotes a vector of unknown parameters; $V_{i t}$ is a two-sided error term signifying the statistical error term whereas $U_{i t}$ is a one-sided error term representing inefficiency. $\ln T C_{i t}=\ln T C\left(P_{i t} Q_{i t} R_{i, t} ; \beta\right)$ is the predicted $\log$ cost function of a cost-minimizing bank operating at $\left(P_{i t} Q_{i t} R_{i t}\right) . V_{i t}$ are random errors that are assumed to follow a symmetrical normal distribution and are independently distributed of $U_{i, t}$; and $U_{i t}$ are identically and independently distributed inefficiency effects. The assumption here is that the $V_{i, t}$ follows a normal distribution with mean 0 and variance $\sigma^{2}{ }_{v}$ and the $U_{i t}$ are half normally distributed.

The profit efficiency function is also specified as follows:

$\operatorname{lnT} P_{i t}=\ln f\left(P_{i t} Q_{i t} ; \beta\right)+\left(V_{i t}+U_{i t}\right) \ldots \ldots \ldots \ldots i=1 \ldots \ldots N$,

where: $T P_{i t}$ represents the observed profit before tax of the ith firm in the ith period and the rest are as defined in equation (1).

With these distributional assumptions, the log-likelihood function of the model is

$\ln L=\frac{N}{2} \ln \frac{2}{\pi}-N \ln \sigma \frac{1}{2 \sigma^{2}} \sum_{i=1}^{N} \in i^{2} \sum_{i=1}^{N} \ln \left[\phi\left(\frac{\in i, \lambda}{\sigma}\right)\right]$

where $\mathrm{N}$ is the number of banks, $\in i=V_{i t}+U_{i t}, \sigma^{2}=\sigma^{2} u+\sigma^{2} v, \quad \chi=\sigma_{u} / \sigma_{v}$, and $\phi($.$) is the standard$ normal cumulative distribution function.

The model can therefore be estimated using the maximum likelihood techniques. After the model has been estimated, inefficiency measures can be computed using the residuals. The average level of inefficiency can be measured as average $(u)$, which is estimated as average $\left(\epsilon^{\wedge}{ }_{i}\right)$ where $\epsilon^{\wedge}$ is the estimated residual for bank i since $u$ is independent of $\mathrm{v}$ and $\mathrm{E}(v)=0$. The mean inefficiency is given by $\mathrm{E}(u)$, which for the half-normal case is $(2 / \pi)^{1 / 2} \sigma u$. This can be estimated as $(2 / \pi) 1 / 2 \sigma_{u}^{\wedge}$ where $\sigma \mathrm{u}^{\wedge}$ is the estimate of $\sigma_{u}$. Because the distribution of the maximum likelihood estimates is known, an approximate standard error of $(2 / \pi) 1 / 2 \sigma_{u}^{\wedge}$ can be calculated.

Bank-level measures of inefficiency are usually given by the mean and mode of the conditional distribution of $u_{i}$, given $\in i$. For the half-normal stochastic model, the conditional distribution of $u_{i}$ given $\epsilon_{\mathrm{i}}$. is a normal distribution, $\mathrm{N}\left(\mu, \sigma^{2}\right)$

\section{The Model Specification}

Again, this study employs the standard translog function as the functional form for the frontier in this work because though the translog and the Fourier flexible functional form yield essentially the same average level and dispersion of measured efficiency, Altunbas and Chakravarty (2001) identified limitations with the Fourier suggesting that the translog is preferred. (Berger and Mester, (1997) and Hassan and Marton, (2003). The standard translog functional model for multi-products is specified as follows: 


$$
\begin{aligned}
\ln \mathrm{TC}=a_{0} & +\sum_{i=1}^{3} a_{i} \ln Q_{i}+\sum_{j=1}^{3} \beta_{j} \ln P_{j}+\tau_{1} \ln R+t_{1} T \\
& +\frac{1}{2}\left[\sum_{i=1}^{3} \sum_{j=1}^{3} \delta_{i j} \ln Q_{i} \ln Q_{j}+\sum_{i=1}^{3} \sum_{j=1}^{3} \gamma_{i j} \ln P_{i} \ln P_{j}+\phi_{1} \ln R \ln R+t T^{2}\right] \\
& +\sum_{i=1}^{3} \sum_{j=1}^{3} \mathrm{q}_{i j} \ln Q_{i} \ln P_{j}+\sum_{I=1}^{3} \Psi_{i} \ln Q_{i} \ln R \\
& +\sum_{i=1}^{3} ¥ i \ln Q_{i}+\sum_{j=1}^{3} \Theta_{j} \ln P_{j} \ln R+\sum_{j=1}^{3} Q T \ln P_{j}+\ln U c+\ln V c \ldots \ldots \ldots
\end{aligned}
$$

TC represents total production cost, comprising total operating expense and financial expense; $Q_{i}(\mathrm{i}=$ $1,2,3$,) represent output quantities, where $Q_{1}$ is gross loans; $Q_{2}$ is other earning assets; $Q_{3}$ is off-balance Sheet items; $P_{j}(\mathrm{j}=1,2,3)$ are input prices, where $P_{1}$ is the price of labour; $P_{2}$ is the price of deposits; $P_{3}$ is the price of physical capital; $R$ is credit risk; T is the time trend, $U_{c}$ are the cost inefficiency components and $V_{c}$ is a random error term.

The frontier above is subject to the following conditions and restrictions

$$
\begin{gathered}
\sum_{j=1}^{3} \beta j=1 \sum_{i=1}^{3} \gamma \mathrm{ij}=0 \sum_{j=1}^{3} \mathrm{q}_{i j}=0 \\
\gamma_{\mathrm{ij}=\gamma_{\mathrm{ji}}=\delta_{\mathrm{ji}}}
\end{gathered}
$$

The study focuses on cost and profit efficiencies as they reflect managerial abilities to minimize costs and maximize revenues respectively. With regards to the profit efficiency estimates, profit functions are estimated in the same manner as the cost functions in equation (4) except that the dependent variable is replaced with total profit on the left side of the equation. Following the justification of Berger and Mester (1997), the researcher rather prefers the alternative profit function instead of the standard profit function. The alternative profit function uses the same variables like the cost function, which means that output prices are free to vary and affect profits. The dependent variable now becomes $\ln (\pi+\theta+1)$, where $\theta$ denotes the absolute value of the minimum value of profits $(\pi)$ overall banks in the sample. This transformation allows the researcher to take the natural log of profits, given that profits can also take negative values. Also, in the case of the profit function, the composite error term becomes $\varepsilon i=v_{i}-u_{i}$, where $u_{i}$, is assumed to follow an exponential distribution.

The profit functional form is as follows:

$$
\begin{aligned}
\ln \mathrm{TP}=a_{0} & +\sum_{i=1}^{3} a_{i} \ln Q_{i}+\sum_{j=1}^{3} \beta_{j} \ln P_{j}+\tau_{1} \ln R+t_{1} T \\
& +\frac{1}{2}\left[\sum_{i=1}^{3} \sum_{j=1}^{3} \delta_{i j} \ln Q_{i} \ln Q_{j}+\sum_{i=1}^{3} \sum_{j=1}^{3} \gamma_{i j} \ln P_{i} \ln P_{j}+\phi_{1} \ln R \ln R+t T^{2}\right] \\
& +\sum_{i=1}^{3} \sum_{j=1}^{3} \mathrm{q}_{i j} \ln Q_{i} \ln P_{j}+\sum_{I=1}^{3} \Psi_{i} \ln Q_{i} \ln R \\
& +\sum_{i=1}^{3} Y_{i} T \ln Q_{i}+\sum_{j=1}^{3} \Theta_{j} \ln P_{j} \ln R+\sum_{j=1}^{3} Q T \ln P_{j}+\ln U p+\ln V p \ldots \ldots \ldots \ldots
\end{aligned}
$$

where TP represents total profit and the rest areas are specified in equation 4 above.

\section{Input, Output and Control Variables for Efficiency Estimation}

There is a continuous debate about what should constitute the outputs and inputs of a financial institution. The intermediation model, which is the main approach specified in literature for estimating 
efficiency in the banking industry, will be employed. The intermediation approach considers banks as financial intermediaries, which mobilize monetary funds from savers and investors and channel these funds to further investment avenues (Sealey and Lindley, 1977). The input variables mostly employed in bank efficiency studies applying the intermediation model are the price of labour, price of deposits and price of physical capital, whereas the output variables mostly used in literature are gross loans and other earning assets (Berger and Mester. 2003; Casu et al, 2004; Beccalli et al., 2006; Altunbas et al., 2001; LozanoVivas et al., 2002; Casu and Molyneaux, 2003; Green et al., 2004; Fries and Taci, 2005; Bonin et al., 2005; Yildrim and Philippatos, 2007; Barry et al., 2011; Afsharian et al, 2011; Casu and Girardone, 2006; Ariff \& Luc, 2008; Isshaq and Bopkin, 2012; Saka et al., 2012; Alhassan and Ohene-Asare, 2016 amongst others). More recently, some studies have utilized off-balance sheet items as part of the output variables since although off-balance sheet items are technically not earning assets, it constitutes an increasing source of income for banks and therefore should be included when modelling banks' cost and profit characteristics, otherwise, total output would tend to be understated. The Impaired Loans to Gross Loans ratio is included in this study to control for the difference in risk preferences. The input, output and control variables used in this study for the estimation of risk-adjusted cost and profit efficiency scores have been summarized in table 1.

TABLE 1

VARIABLES USED IN RISK-ADJUSTED EFFICIENCY ESTIMATION

\begin{tabular}{|c|c|c|}
\hline List of variables & Measurement & Acronym \\
\hline \multicolumn{3}{|l|}{ Input variables } \\
\hline Deposits & Total Customer Deposits & $\mathrm{CD}$ \\
\hline Labour & Total Staff Cost & $\mathrm{SC}$ \\
\hline Physical Capital & Total Non-Current Assets \& Software Cost & $\mathrm{PC}$ \\
\hline Input Prices & & \\
\hline Price of Deposits & Total Interest Expense/Total Deposits & POD \\
\hline Price of Labour & Total Labour Expense/ Total Assets & POL \\
\hline Price of Physical Capital & $\begin{array}{l}\text { (Total Depreciation \& Software } \\
\text { Amortization)/(Total Non-Current Assets \& } \\
\text { Software Cost) }\end{array}$ & POC \\
\hline \multicolumn{3}{|l|}{ Output Variables } \\
\hline Loans & $\begin{array}{l}\text { Gross Loans and Advances to Customers and } \\
\text { Banks }\end{array}$ & TLS \\
\hline Other Earning Assets & Security Investments and other Earning Assets & OEA \\
\hline Off-Balance Sheet Items & $\begin{array}{l}\text { Guarantees, Acceptances and Documentary } \\
\text { Credits Reported Off-Balance Sheet }\end{array}$ & OBS \\
\hline Controlling Variable & & \\
\hline Credit Risk & Impaired Loans/ Gross Loans & NPL \\
\hline Total Cost & Total Financial and Operating Cost & $\mathrm{TC}$ \\
\hline Total Profit & Profit Before Tax & $\mathrm{TP}$ \\
\hline
\end{tabular}

\section{Second-Stage Regression}

Many studies have regressed frontier efficiency estimates on certain covariates and other variables in the so-called two-stage processes to determine how the exogenous variables can affect the efficiency levels of decision-making units (Simar \& Wilson, 2007; 2011). These variables may influence the efficiency estimates generated in the first stage such as the cost and profit efficiency estimates. Simar and Wilson (2007) argued that frontier efficiency estimates from the first stage may be serially correlated in an unknown 
and complicated manner. Thus, regressing these estimates on certain exogenous covariates without recognizing this deficiency could result in invalid inferences.

To resolve the deficiency of serial correlation, preceding studies adapted the Tobit regression models (in the two-stage, SFA plus regression approach) due to the censored nature of SFA scores. Simar and Wilson $(2007,2011)$ criticized these studies on the basis that the first stage dependency issue suggests that the stochastic error term of the Tobit regression is correlated with the other variables making Tobit estimation inappropriate. The outcome is that inferences made on the second-stage parameters will be biassed and inconsistent. Also, although, employing maximum likelihood in the stage-two analysis implies that this correlation vanishes asymptotically, it occurs at a very slow pace and may produce invalid inference. To address these, Simar and Wilson (2007) have proposed a double-bootstrapped truncated regression when undertaking a second-stage regression whereby the efficiency estimates are regressed on some other variables instead of OLS or Tobit estimates. This is to permit valid inferences and improve the statistical efficiency of the second-stage estimates. McDonald (2009) and Banker and Natarajan (2008) have in recent times argued that Ordinary Least Squares (OLS) produces consistent estimates in the secondstage regression. Similarly, Banker and Natarajan (2008) and Ramalho et al., (2010) have noted the computational burden of bootstrapping and the fact that more bootstrap replications are required for convergence to be achieved. This study employs the panel least square, given this, for the second-stage regression.

\section{Liquidity, Capital, and Efficiency}

In estimating the effects of liquidity and capital on the cost efficiency of banks, the following model is applied:

$C E_{i t}=a_{0}+\beta_{1} L I Q_{i t}+\beta_{2} C A P_{i t}+\beta_{3} C O N C_{i t}+\beta_{4} S I Z E_{i t}+v_{i t} \ldots+\varepsilon_{i} \ldots \ldots \ldots$

where: $C E_{i t}$ is the cost efficiency of bank $i$ at time $t ; L I Q_{i t}$ is the liquidity of bank i at time $\mathrm{t}$; $C A P_{i t}$ is the capital of bank i at time t; $C O N C_{i t}$ is the concentration of bank i at time t; $S I Z E_{i t}$ is the size of bank i at time $\mathrm{t} ; v_{i, t}$ is the random error and $\varepsilon_{i}$ is the unobserved bank-specific error; $a_{0}$ is the intercept of the model and $\beta_{1}, \beta_{2}, \beta_{3}, \beta_{4}$ are the regression model coefficients to be estimated.

The estimation of the effect of liquidity and capital on the profit efficiency of banks applies the following model:

$P E_{i, t}=a_{0}+\beta_{1} L I Q_{i, t}+\beta_{2} C A P_{i, t}+\beta_{3} \operatorname{CONC}_{i, t}+\beta_{4} S I Z E_{i, t}+v_{i, t} \ldots+\varepsilon_{i} \ldots \ldots \ldots$

where $P E$ is profit efficiency of bank i at time $\mathrm{t}$ and the rest are as defined in equation (9)

\section{Variable Measurements}

Bank size is proxied by the natural logarithm of the bank's total assets, consistent with the study of Altunbas et al. (2007); Tecles and Tabak (2010) and others. In this paper, we theorize that increase in the size of a bank or the scale of a bank's operations will lead to a rise in inefficiency. Banks are likely to obtain cost reductions resulting from a decrease in per-unit cost as a result of an increase in size or scale of operations (Srairi, 2010). Size is introduced to control for the differences in the size of the banks. Concentration is also proxied by the Herfindahl-Hirschman index (HHI), consistent with Wong et al (2007). Wong et al (2007), examine the extent to which indicators of market structure, including concentration, influence the efficiency of banks in Hong Kong, by employing the Panzar-Rosse approach and the conjectural variation approach and conclude that concentration is a key determinant of efficiency. 


\section{RESULTS AND DISCUSSION}

\section{Descriptive Statistics of Variables for Risk-Adjusted Efficiency Estimation}

There is usually some controversies in banking literature surrounding the specification of input and output for necessary frontier modelling. Empirical literature recognizes that the results of efficient studies can be influenced by the choice of variables utilized. Therefore, it becomes imperative to describe the variables used for the efficiency to ensure that they are in tandem with the necessary assumptions required for effective estimations. The dataset employed in this study was sourced from the banking supervision department of the BOG and cross-validated with similar data from the annual financial reports of the seventeen universal banks. The summary statistics of the variables employed in the estimation of riskadjusted cost and profit efficiencies of banks in Ghana are reported in table 4. A-year-by year summary statistics of these variables have also been attached in appendix A.

TABLE 2

SUMMARY STATISTICS OF VARIABLES USED IN RISK-ADJUSTED COST AND PROFIT EFFICIENCIES ESTIMATION

\begin{tabular}{|c|c|c|c|c|c|}
\hline VARIABLES & MEAN & STD DEV & MIN & MAX & GM \\
\hline \multicolumn{6}{|l|}{ INPUT PRICES } \\
\hline POL & 0.037917 & 0.036648 & 0.004152 & 0.4072 & 0.032397 \\
\hline POD & 0.059304 & 0.031905 & 0.013819 & 0.212766 & 0.051755 \\
\hline POPC & 0.175924 & 0.100174 & 0.01398 & 0.4722 & 0.143225 \\
\hline \multicolumn{6}{|l|}{ CONTROLLING } \\
\hline CREDIT RISK & 0.110011 & 0.069409 & 0.01286 & 0.5103 & 0.090069 \\
\hline \multicolumn{6}{|l|}{ OUTPUT } \\
\hline TLS ( $\left.\varnothing^{\prime} M I L L I O N\right)$ & $1,033.299$ & 817.5032 & 13.4 & 4,150 & 722.8995 \\
\hline OEA(ф’MILLION) & 869.4126 & 718.9351 & 41.5 & $3,240.3$ & 567.0238 \\
\hline OBS( $\varnothing^{\prime}$ MILLION) & 380.8277 & 366.6302 & 0.5 & $2,202.5$ & 212.9393 \\
\hline \multicolumn{6}{|l|}{ OTHERS } \\
\hline TC( $\left.\varnothing^{\prime} M I L L I O N\right)$ & 248.8386 & 202.9847 & 9.7 & $1,215.737$ & 178.4482 \\
\hline TP( $\notin^{\prime}$ MILLION $)$ & 108.3623 & 133.8928 & -105.714 & 550.256 & \\
\hline T/ASSETS( $\varnothing^{\prime}$ MILLION) & $2,401.658$ & $2,075.56$ & 94.7 & $10,720.93$ & $1,664.779$ \\
\hline
\end{tabular}

An analysis of the input prices shows that on average, the most expensive factor of production in the Ghanaian banking industry is the price of physical capital ( $\mathrm{GH} \not 0.18)$ which is common in most developing countries. Again, the reported results suggest that on average, the staff cost of banks in Ghana is approximately 3.79 per cent of their total assets. Guarantees, acceptances and documentary credits reported off-balance sheet constituted approximately 17 per cent of the total output of the banks during the period. This implies that off-balance sheet items constitute a significant proportion of the total output generated by the banks. The results reported also show that banks in Ghana gave out approximately $54.30 \%$ of their customer deposits as loans and advances to their customers and invested approximately $45.69 \%$ in other earning assets for the period under consideration. Non-performing loans are approximately $11 \%$ of total bank loans whereas total loans and investments in other earning assets are, on average, around $43 \%$ and $36.2 \%$ of total bank assets respectively. Correlation among the variables is usually negligible 
The minimum and maximum values of the total assets of the banks ( $\min =\mathrm{GH} \notin 94,700,000, \max =$ GH $\notin 10,720,930,000)$ and their relatively high standard deviations reveal that banks in Ghana have different sizes. This provides some justification for the utilization of the Variable Returns to Scale (VRS) assumption of Banker et al. (1984) in the estimation of efficiency. The minimum and maximum values of the gross loans, other earning assets and off-balance sheet items of the banks [min (TLS $=\mathrm{GH} \phi 13,400,000, \mathrm{OEA}=$ $\mathrm{GH} \notin 41.500,000, \mathrm{OBS}=\mathrm{GH} \phi 500,000) ; \max (\mathrm{TLS}=\mathrm{GH} \phi 4,150,000,000, \mathrm{OEA}=\mathrm{GH} \notin 3,240,300.000, \mathrm{OBS}$ $=\mathrm{GH} \propto 2,202,500,000)$ and their relatively high standard deviations also suggest that banks in Ghana have different scale of operations. Further, the relatively high standard deviations of the outputs, prices of inputs and capital suggest that the actual averages of these variables are largely dispersed from the expected suggesting volatility in the variables over the ten years.

As can be seen from the standard deviation of the three input prices variables, we can conclude that the difference in the price of physical capital among Ghanaian banks is larger than the differences in the price of labour and price of deposits. As one important part of non-financial operating expenses, some of the banks have either construct or acquire their buildings in multiple locations and use them as branch offices and banking halls in a bid to increase their market shares and also announce their presence in such locations. They also employ sophisticated and expensive software packages to make possible the delivery of complex products or services. On the other hand, some other banks do not engage in massive construction or acquisition of buildings for operational purposes; or employ sophisticated and expensive software for their operations. Among the three input price variables, the difference in cost of deposits is the smallest among banks operating in Ghana. The differences of outputs variables among the banks are much larger, while the largest differences are found on total loans. This is mainly due to the size of the banks. For example, banks like Ghana Commercial Bank, Ecobank, Standard Chartered Bank and Barclays bank have comprehensive branches around the country and also serve businesses and other entities with larger demands for funds. Further, some of the relatively small banks focus their businesses within the urban centres, hence, the businesses they serve are relatively smaller.

FIGURE 1

TREND ANALYSIS OF AVERAGE OUTPUT QUANTITIES FROM 2009 TO 2018

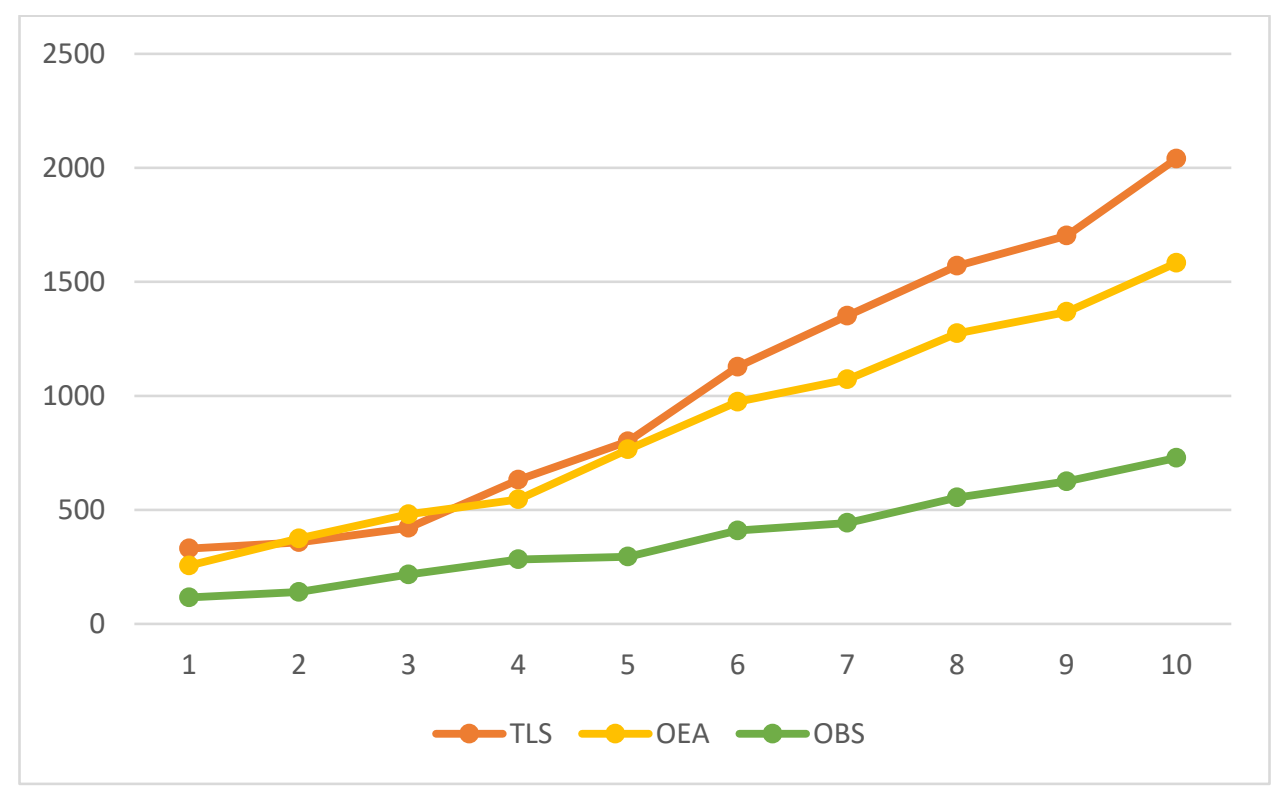

A trend analysis of the output variables (as shown in Figure 1) shows that there has been a steady rise in all the output. The rise in other earning assets and its closeness to gross loans is probably because of the increase in the discount rate of treasury bills. The discount rate of the 91-day treasury bill, 182-day treasury 
bill and 364-day treasury bill all increased over the period under consideration till 2018 when it experienced a slight decline (BOG, 2019), which made investments in government securities attractive to banks.

\section{FIGURE 2 \\ TREND ANALYSIS OF AVERAGE INPUT PRICES FROM 2009 TO 2018}

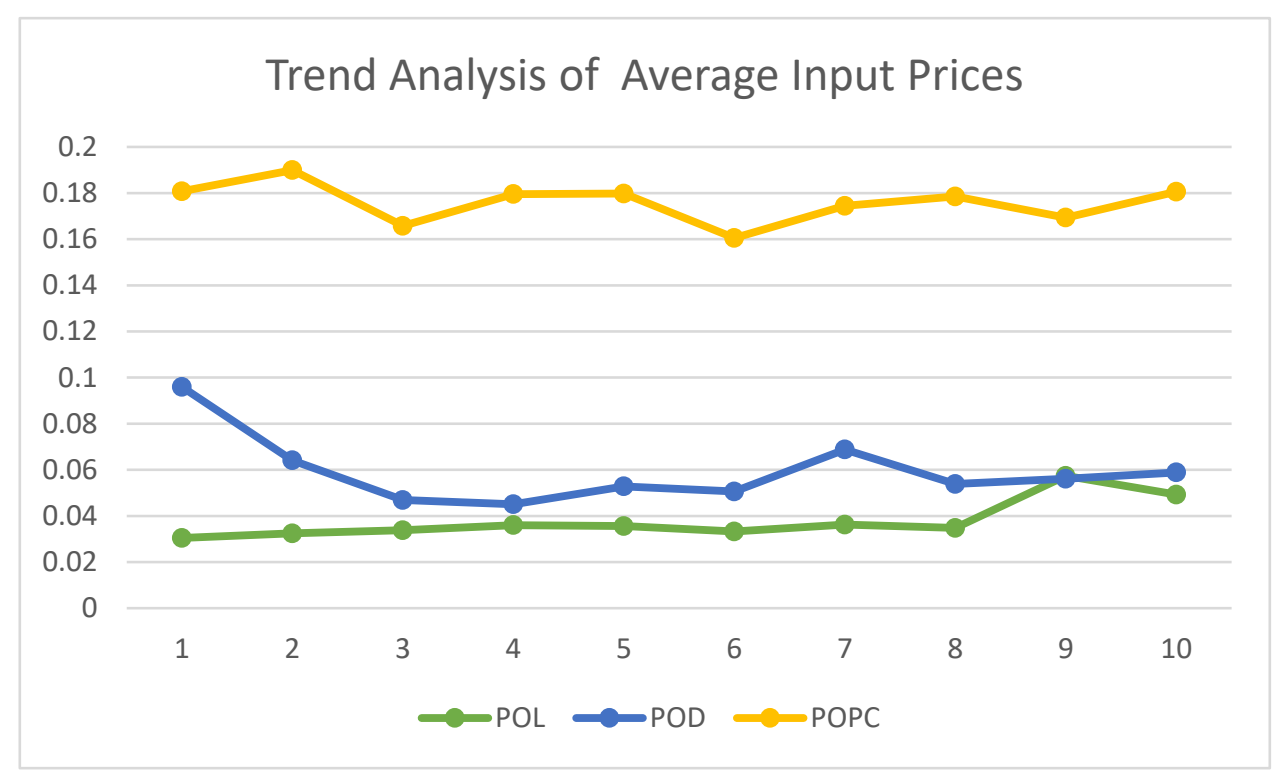

The price of physical capital increased slightly in 2010 and decreased marginally in 2011 and then experienced a very slight increase in 2012 before flattening the curve for the rest of the period. The price of deposits experienced a downward trend till 2013 when it increased marginally and then maintained a flat curve for the rest of the period. The price of labour maintained a flat curve till 2017 where it experienced an increase but dropped slightly in 2018 .

\section{Cost and Profit Efficiency Estimates of Banks in Ghana}

To enable the achievement of the first two objectives of the study, the risk-adjusted cost and profit efficiency scores of the banks under consideration for each year is calculated under VRS. For generalization, the means and standard deviations of the risk-adjusted cost and profit efficiency scores estimated are reported in Table 3.

The Gamma parameter in appendix B shows the proportion of the variance in disturbance due to inefficiency and takes a value between 0 and 1 . Values close to one are indicative that the variation of inefficiency is more important than other stochastic variations in the frontier model. The Gamma values of the cost and profit frontier models are 0.981 and 0.936 respectively, meaning that the variation of inefficiency is more important than other stochastic variations in both the cost and profit frontier models. In other words, the values in both cases suggest that majority of residual variation is a result of the inefficiency effect and that the random errors are about $2 \%$ and $6 \%$ respectively for cost and profit frontier models. Lambda which captures the ratio of inefficiency standard deviation to the standard deviation of other stochastic factors is positive and significant in both frontier models.

Table 3 presents the average yearly risk-adjusted cost and profit efficiency estimates of banks in Ghana between the period 2009 and 2018. According to (Ohene-Asare and Asmild, 2012), using arithmetic mean alone may lead to wrong inferences, hence the computation of both arithmetic and geometric means. It can be seen from Table 3 that the banks generally experience a slight increase in both risk-adjusted cost and profit efficiencies over the period under consideration. The high levels of the risk-adjusted cost and profit efficiencies accompanied by lower standard deviations suggest that most banks operating in Ghana lie close to the benchmark cost and profit frontiers. 
TABLE 3

AVERAGE YEARLY RISK-ADJUSTED COST AND PROFIT EFFICIENCY ESTIMATES

\begin{tabular}{l|lll|lll}
\hline \multirow{2}{*}{ YEAR } & CE & & & PE & & \\
& $\boldsymbol{A M}$ & $\boldsymbol{S T D}$ & $\boldsymbol{G M}$ & $\boldsymbol{A M}$ & $\boldsymbol{S T D}$ & $\boldsymbol{G M}$ \\
\hline 2009 & 0.654 & 0.062 & 0.652 & 0.583 & 0.050 & 0.580 \\
2010 & 0.656 & 0.051 & 0.654 & 0.584 & 0.040 & 0.583 \\
2011 & 0.667 & 0.055 & 0.665 & 0.591 & 0.043 & 0.590 \\
2012 & 0.658 & 0.039 & 0.657 & 0.599 & 0.045 & 0.597 \\
2013 & 0.675 & 0.043 & 0.674 & 0.608 & 0.050 & 0.606 \\
2014 & 0.686 & 0.040 & 0.685 & 0.619 & 0.047 & 0.685 \\
2015 & 0.689 & 0.044 & 0.688 & 0.625 & 0.045 & 0.623 \\
2016 & 0.693 & 0.042 & 0.691 & 0.636 & 0.042 & 0.635 \\
2017 & 0.700 & 0.041 & 0.699 & 0.635 & 0.045 & 0.633 \\
2018 & 0.710 & 0.042 & 0.709 & 0.647 & 0.045 & 0.645 \\
\hline MEAN & 0.678882 & 0.048888 & 0.677149 & 0.612582 & 0.049124 & 0.610582 \\
\hline
\end{tabular}

On average, $61 \%$ of the potential profits that a best practice bank could make under similar conditions are earned by most of the banks whiles the best practice banks incur approximately $68 \%$ of the cost incurred by most of the banks. The average risk-adjusted cost efficiency for the banks stands at approximately $68 \%$, meaning that universal banks operating in Ghana could reduce their costs by almost $32 \%$ on average, to match their performance with the best practice universal banks in the sample. The average risk-adjusted profit efficiency for the banks also stands at approximately $61 \%$, suggesting that universal banks operating in Ghana could increase their profits since they are earning only $61 \%$ on average of what the best practice universal banks in the sample are earning.

It can be concluded here that universal banks operating in Ghana still have room for cost efficiency improvement by producing the same level of outputs with lower costs or by generating more outputs using the same level of costs. Improving profit efficiency can also be done by generating more revenues using the same level of input prices or generating the same level of revenues using lower input prices.

Furthermore, it can be seen that cost efficiency estimates are, on average, higher than profit efficiency estimates in each of the years studied. This brings to light the importance of considering the revenue side in efficiency measurement that is not taken into account when concentrating only on the cost side. This result is similar to the few studies that compare bank cost efficiency and profit efficiency, such as Maudos et al. (2002); Hollo and Nagy (2006) and Afsharian et al. (2011) for the case of European banking systems and Berger and Mester (1997) in the case of US banking systems. It can also be said that the room for universal banks operating in Ghana to improve their profit efficiency is larger than it is to improve their cost-efficiency.

\section{Efficiency Estimates and Explanatory Variables}

The summary statistics of the variables used in the panel least square regression are presented in table 4. 
TABLE 4

SUMMARY STATISTICS OF VARIABLES USED IN REGRESSION ANALYSIS

\begin{tabular}{l|lllll}
\hline VARIABLES & MEAN & STD DEV & MIN & MAX & GM \\
\hline INDEPENDENT & & & & & \\
CAP & 0.149399 & 0.072556 & 0.008924 & 0.832101 & 0.138159 \\
LIQ & 0.551445 & 0.186255 & 0.03376 & 1.37234 & 0.512294 \\
& & & & & \\
CONTROLLING & & & & & \\
CONC & 0.078736 & 0.005473 & 0.071905 & 0.09085 & 0.078553 \\
SIZE & 3.221357 & 0.394813 & 1.97635 & 4.030232 & 3.196238 \\
& & & & & \\
DEPENDENT & & & & & \\
CE & 0.678882 & 0.048888 & 0.593 & 0.794 & 0.677149 \\
PE & 0.612582 & 0.049124 & 0.511 & 0.698 & 0.610582 \\
\hline
\end{tabular}

To investigate the marginal effect of liquidity and capital on the risk-adjusted cost efficiency and riskadjusted profit efficiency of universal banks operating in Ghana (the third and fourth objectives of this study), a panel least square regression is estimated. This involves regressing risk-adjusted cost efficiency on liquidity, capital and other control variables. Also, risk-adjusted profit efficiency is regressed on liquidity, capital and other control variables. To undertake this, the study first tests for the degree of multicollinearity among the various independent variables. Table 6 presents the correlate on a matrix for the independent variables.

TABLE 5

CORRELATION MATRIX

\begin{tabular}{lcccc}
\hline VARIABLE & CONC & SIZE & CAP & LIQ \\
\hline CONC & 1.000 & & & \\
SIZE & -0.074 & 1.000 & & \\
CAP & -0.141 & 0.626 & 1.000 & 1.000 \\
LIQ & 0.192 & 0.183 & -0.443 & \\
\hline
\end{tabular}

The correlation matrix shows a negative and a very weak correlation between concentration and bank size. There also exist a negative and a very weak correlation between concentration and bank capital. There is however a positive but very weak correlation between concentration and liquidity. Banks size and capital correlate positively and strongly with bank capital. There exists a positive but weak correlation between bank size and liquidity. Bank capital correlates negatively with liquidity.

When specifying a model, independent variables that are correlated (have values exceeding 0.50) cannot be placed in the same model (Cohen, 1988). The reason is that they play similar roles and including them in the same model may make the regression sensitive to small changes in specification. With this situation, the confidence intervals for the parameters will be wide and the conclusions that might be made from the significance tests may be inappropriate (Brooks, 2008). To resolve this multicollinearity situation, it is required that one of the highly correlated independent variables be excluded from the model to avoid model misspecification. This can be achieved through the use of the Variance Inflation Factor which quantifies the severity of multicollinearity through a stepwise procedure. 
Some econometricians have however argued that dropping an independent variable that belongs to the population model can lead to biases (Wooldridge, 2012). Also, setting an arbitrary cutoff point for the Variance Inflation Factor above which multicollinearity is a problem is questionable and not particularly useful. Thus, the multicollinearity problem can be ignored if the model is adequate in terms of the coefficients having the correct signs and being of a plausible magnitude.

Again, multicollinearity is less a problem with the model than with the data (Brooks, 2008). Given the above, the multicollinearity between bank size and capital (0.626) is ignored.

The Hausman specification test, which is a test performed to determine whether the study should utilize the fixed-effects or random-effects model estimation before the running of a panel regression was applied. The rule of thumb for the Hausman test is that when $\mathrm{p}<0.05$, there is a correlation between the error terms and the explanatory variables and a fixed-effects estimation is adopted else the random effects estimator is deemed to be more appropriate. The test showed that a random-effects estimator is more appropriate for using both risk-adjusted cost efficiency and risk-adjusted profit efficiency as the dependent variables in both regressions. The Hausman test generates an insignificant Chi-square value supporting the use of random effects in both models. (see Appendix $\mathrm{C}$ for results on the Hausman Test). The BreuschPagan/Cook-Weisberg test for heteroscedasticity shows that both models do not suffer from heteroscedasticity, as reported in Appendix C, where the values of Chi-square in both models are insignificant. The Wooldridge test for autocorrelation, as shown in appendix C, also generates an insignificant F-value for both models, showing that the null hypothesis that there is no serial correlation cannot be rejected.

\section{Effect of Liquidity and Capital on Cost Efficiency}

The random-effects regression results for risk-adjusted cost efficiency are presented in table 6 . The results show that bank size as measured by the natural log of total bank assets has a positive and statistically significant relationship with risk-adjusted cost efficiency.

TABLE 6

REGRESSION RESULTS FOR RISK-ADJUSTED COST EFFICIENCY

\begin{tabular}{ll}
\hline VARIABLES & \\
\hline Intercept & 0.132862 \\
& $(0.120047)$ \\
CONC & -0.310860 \\
& $(0.356591)$ \\
SIZE & $0.427836^{* *}$ \\
& $(0.207392)$ \\
LIQ & $0.644487 * *$ \\
& $(0.289612)$ \\
CAP & $0.370920 * * *$ \\
& $(0.117340)$ \\
\hline R-Squared & 0.3497 \\
\hline F-statistic & $7.74 * * *$ \\
\hline Hausman Test & 4.84 \\
\hline BP/CW LM Test & 0.69 \\
\hline Wooldridge Test & 1.143 \\
\hline$* * *, * *$ and $*$ indicate $1 \%, 5 \%$ and $10 \%$ significance levels, respectively, and standard errors in parentheses
\end{tabular}


This means that the risk-adjusted cost efficiency of banks tends to increase when banks expand in size. These findings are consistent with the findings of Hasan and Marton (2003), Matousek and Taci (2004), Yildirim and Philippatos (2007), Srairi (2010). The increase in bank size increasing risk-adjusted cost efficiency is probably because banks are likely to obtain cost reductions resulting from a decrease in perunit cost as a result of an increase in size or scale of operations. Another reason for this relationship may be the fact that larger banks enjoy economies of scale, are more diversified and develop better means and prospects for diversifying risk than smaller banks (Isik \& Hassan, 2002; Tecles \& Tabak, 2010; Srairi, 2010).

The regression results also suggest that liquidity, as measured by the ratio of net loans to total deposits and short term funding, has a positive and statistically significant impact on risk-adjusted cost efficiency. This implies that increase in liquidity results in increased risk-adjusted cost efficiency. These findings are consistent with McKillop et al, (2002). This relationship is probably because banks holding more liquid assets benefit from a superior perception in funding markets, reducing their financing costs and increasing profitability, thereby improving their output/input and profit/input ratios. Higher liquid assets reduce the illiquidity and financing cost of banks. Liquid banks are expected to be more efficient in the sense that, all other things being equal, liquid banks can produce more output in the form of loans and other interestearning assets as opposed to illiquid banks which does not have the liquidity to meet the demands such output. This finding also satisfies hypothesis one (H1a) and implies that, in Ghana, risk-adjusted efficiency is associated with liquidity. This finding is however different from the findings of Said (2013), which saw an insignificant relationship between bank liquidity and efficiency.

Bank capital, as measured by the ratio of total shareholders fund (equity, retained earnings and other disclosed equity reserves) to total bank assets, has a positive and statistically significant impact on riskadjusted cost efficiency, as shown by the panel regression results. This indicates that bank capital is important in determining the risk-adjusted cost efficiency of banks and an increase in bank capital results in an increase in risk-adjusted cost efficiency. This finding is consistent with Fiordelisi et al (2011), who find that higher capital ratios are associated with higher bank efficiency in the European banking industry. The finding is also in tandem with Pessarossi and Weill (2013), who find that an increase in capital in the Chinese banking industry has a positive effect on cost efficiency, the size of which depends to an extent on the bank's ownership type. This effect may emanate from reduced moral hazard between shareholders and debenture holders. As a result of the limited liability of shareholders, low capital ratios increase their incentives to take on excessive risk. This behaviour may also be reinforced by explicit or implicit government guarantees of deposits. A higher capital ratio, therefore, has the potential of reducing riskshifting and increasing shareholders' incentive to control risk. Again, by increasing the surplus derived in the bank-borrower relationship and by improving monitoring incentives, capital ratios tend to have a positive effect on the efficiency of banks. The finding is however not consistent with Berger and Bonaccorsi (2006), who find that lower capital ratios are associated with higher bank efficiency.

\section{Effect of Liquidity and Capital on Profit Efficiency}

The random-effects regression results for risk-adjusted cost efficiency are presented in table 7 . With regards to the risk-adjusted profit efficiency as a dependent variable, the random effects regression results show that there exists a statistically significant relationship between bank size and risk-adjusted profit efficiency. However, unlike the risk-adjusted cost efficiency, bank size hurts risk-adjusted profit efficiency. This means that smaller banks are more efficient in terms of earning profits than their larger counterparts. 
TABLE 7

REGRESSION RESULTS FOR RISK-ADJUSTED PROFIT EFFICIENCY

\begin{tabular}{ll}
\hline VARIABLES & \\
\hline Intercept & 0.124385 \\
& $(0.309530)$ \\
CONC & 0.070604 \\
& $(0.348570)$ \\
SIZE & $-0.426743 * *$ \\
& $(0.207775)$ \\
CAP & $0.467563 * * *$ \\
& $(0.117991)$ \\
LIQ & $0.624944 * *$ \\
& $(0.285061)$ \\
\hline R-Squared & 0.3926 \\
\hline F-statistic & $7.39 * * *$ \\
\hline Hausman Test & 4.76 \\
\hline BP/CW LM Test & 1.01 \\
\hline Wooldridge Test & 1.528 \\
\hline ***,** and * indicate $1 \%, 5 \%$ and $10 \%$ significance levels, respectively, and standard errors in parentheses
\end{tabular}

This finding does not stand in line with expectations and is also not consistent with the concept of toobig-to-fail, where larger banks invest in highly risky assets leading to higher profitability. This might be because smaller banks in the Ghanaian banking industry issue more risky loans or deal with small size customers in return for higher interest rates.

The panel regression results also show that bank liquidity has a positive and statistically significant impact on the risk-adjusted profit efficiency of banks. This suggests that an increase in liquidity leads to an increase in risk-adjusted profit efficiency. This outcome is also similar to that obtained by Altunbas et al (2007) and McKillop et al (2002). This stands in line with expectations that higher liquid assets reduce the illiquidity and financing cost of banks. Liquid banks are expected to be more efficient in the sense that, all other things being equal, liquid banks can produce more output in the form of loans and other interestearning assets as opposed to illiquid banks which does not have the liquidity to meet the demands such output. This relationship might also be due to the fact banks holding more liquid assets benefit from a superior perception in funding markets, reducing their financing costs and increasing profitability, thereby improving their output/input and profit/input ratios. This finding is however different from the findings of the studies of Said (2013), which saw an insignificant relationship between bank liquidity and efficiency in the banking industry of the MENA region.

The regression results also show bank capital has a positive and statistically significant impact on riskadjusted profit efficiency. This implies that the level of bank capital is important in determining the riskadjusted profit efficiency of banks and an increase in bank capital results in an increase in risk-adjusted profit efficiency. This finding is consistent with Fiordelisi et al (2011) and Pessarossi and Weill (2013). The result also satisfies hypothesis two (H2b) and suggests that, in Ghana, the capital level is an important determinant of the profit efficiency of banks. This effect might probably emanate from reduced moral hazard between shareholders and debenture holders. As a result of the limited liability of shareholders, low capital ratios increase their incentives to take on excessive risk. This behaviour is may also be reinforced by explicit or implicit government guarantees of deposits. A higher capital ratio, therefore, has the potential of reducing risk-shifting and increasing shareholders' incentive to control risk. Again, by increasing the surplus derived in the bank-borrower relationship and by improving monitoring incentives, capital ratios 
tend to have a positive effect on the efficiency of banks. This relationship is however contrary to the tradeoff theory, which states that using less capital and more leverage reduces the tax burden of banks and helps them give out more loans from which they generate higher interest incomes. The result is also not consistent with the principle that using more leverage as opposed to equity capital may also reduce the agency costs predominant in these banks leading to higher profit efficiency.

\section{CONCLUSION}

The findings of the study reveal that average risk-adjusted cost efficiency and risk-adjusted profit efficiency levels in the Ghanaian banking industry are quite high, indicating an industry that is quite sound and economically viable. There is however more room for improvement based on effective policy directions and regulatory controls. Regulators should accelerate the process of restructuring and reform of the banking system to facilitate greater efficiency of banks since a more efficient banking industry has implications for financial stability and economic growth. Ensuring efficiency in the banking system leads to the enhancement of the entire financial structure because banks are the main financial intermediation channels.

Another major finding of the study is the relationship between bank liquidity and risk-adjusted efficiency. The result implies that an increase in bank liquidity increases both risk-adjusted cost efficiency and risk-adjusted profit efficiency. This provides clear empirical evidence that bank liquidity is crucial in ensuring efficiency in the banking system. It is therefore imperative that banks carefully formulate their policies on raising and allocating funds while at the same time, comply with the proposed regulatory liquidity requirements. Ensuring adequate liquidity is essential in banking operations because of the financial intermediation role of banks by transforming short term deposits to long term loans. The fact that efficient banks benefit from cost minimization or profit maximization presents them with incentives to invest in large amounts of loans and instruments which may also come with high risk. Regulators closely monitor these banks and their loan portfolios. There is therefore the need for regulatory measures and liquidity standards to discourage excessive risk-taking behaviour. The study findings also imply the need for money market development to provide liquidity for banks.

The relationship between capital and risk-adjusted efficiency is the next major finding. The results reveal that increase in the level of bank capital tends to increase both risk-adjusted cost efficiency and riskadjusted profit efficiency. This finding conforms to the less moral hazard hypothesis in shareholders' behaviour if their stakes in the bank are larger. The result implies that in the Ghanaian banking industry, an increase in the capital ratio improves both risk-adjusted cost efficiency and risk-adjusted profit efficiency on average. Thus, the results suggest that capital requirements do not only strengthen financial stability by providing a larger capital buffer, but also improve bank efficiency by lowering moral hazard between shareholders and debt-holders. Therefore, the prudential regulation on capital requirements does not appear to suffer from a trade-off between bank performance and increasing the soundness of the financial sector.

The results also show that increase in bank size is related to increase risk-adjusted cost efficiency but leads to a decrease in risk-adjusted profit efficiency. This finding suggests that large banks are more efficient than smaller banks in terms of cost minimization whereas smaller banks are also more efficient than large banks in terms of earning profits. Large universal banks should appropriately take advantage of their size, aligning with the theory of conventional economic efficiency to obtain optimal efficiency. Smaller banks should also adopt proper screening measures and effective credit control mechanisms to enhance their cost-efficiency. 


\section{REFERENCES}

Afsharian, M., Kryvko A., \& Reichling, P., (2011). Efficiency and its impacts on European commercial banks. Journal of Banking and Finance, 37(13), 2533-2555.

Alhassan, A.L., \& Ohene-Asare, K. (2016). Competition and bank efficiency in emerging markets: Empirical evidence from Ghana. African Journal of Economic and Management Studies.

Allen, F., \& Gale, D. (2004). Competition and financial stability. Journal of Money, Credit and Banking, pp. 453-480.

Altunbaş, Y., \& Chakravarty, S.P. (2001). Frontier cost functions and bank efficiency. Economics Letters, $72(2), 233-240$.

Altunbas, Y., Carbo, S., Gardener, E., \& Molyneux, P. (2007). Examining the relationships between capital, risk and efficiency in European banking. European Financial Management, 13(1), 49-70.

Altunbas, Y., Evans, L., \& Molyneux, P. (2001). Bank ownership and efficiency. Journal of Money, Credit and Banking, pp. 926-954.

Altunbas, Y., Gardener, E.P.M., Molyneux, P., \& Moore, B. (2000). Efficiency in European banking. European Economic Review, 45(10), 1931-1955.

Ariff, M., \& Luc, C. (2008). Cost and profit efficiency of Chinese banks: A non-parametric analysis. China Economic Review, 19(2), 260-273.

Baltagi, B.H. (2008). Forecasting with panel data. Journal of Forecasting, 27(2), 153-173.

Bank of Ghana. (2018). BOG banking sector report vol. 11 No 1/2018.

Bank of Ghana. (2019). BOG monetary policy report vol. 6 No 1/2019.

Banker, R.D., \& Natarajan, R. (2008). Evaluating contextual variables affecting productivity using data envelopment analysis. Operations Research, 56(1), 48-58.

Banker, R.D., Chang, H., \& Lee, S.Y. (2010). Differential impact of Korean banking system reforms on bank productivity. Journal of Banking \& Finance, 34(7), 1450-1460.

Banker, R.D., Charnes, A., \& Cooper, W.W. (1984). Some models for estimating technical and scale inefficiencies in data envelopment analysis. Management Science, 30(9), 1078-1092.

Barry, T.A., Lepetit, L., \& Tarazi, A. (2011). Ownership structure and risk in publicly held and privately owned banks. Journal of Banking and Finance, 35, 1327-1340.

Barth, J.R., Caprio, G., \& Levine, R. (2013). Bank regulation and supervision in 180 countries from 1999 to 2011. Journal of Financial Economic Policy.

Basle Committee on Banking Supervision. (2000, September). Principles for the Management of Credit Risk. Retrieved from http://www.bis.org/publ/bcbs75.pdf

Beccalli, E., Casu, B., \& Girardone, C. (2006). Efficiency and stock performance in European banking. Journal of Business Finance \& Accounting, 33(1-2), 245-262.

Berger A., \& Bonaccorsi di Patti, E. (2006). Capital structure and firm performance: A new approach to testing agency theory and an application to the banking industry. Journal of Banking \& Finance, (30), 1065-1102.

Berger, A.N., \& Bouwman, C.H. (2009). Bank liquidity creation. The Review of Financial Studies, 22(9), 3779-3837.

Berger, A.N., \& DeYoung, R. (1997). Problem loans and cost efficiency in commercial banks. Journal of Banking \& Finance, 21(6), 849-870.

Berger, A.N., \& Mester, L.J. (1997). Inside the black box: What explains differences with efficiency of financial institutions. Journal of Banking and Finance, 21, 895-947.

Berger, A.N., \& Mester, L.J. (2003). Explaining the dramatic changes in performance of US banks: Technological change, deregulation, and dynamic changes in competition. Journal of Financial Intermediation, 12(1), 57-95.

Berger, A.N., Hunter, W.C., \& Timme, S.G. (1993). The efficiency of financial institutions: A review and preview of research past, present and future. Journal of Banking \& Finance, 17(2-3), 221-249.

Bonin, J., Hassan, I., \& Wachtel, P. (2005). Bank performance, efficiency and ownership in transition countries. Journal of Banking and Finance, 29, 31-53. 
Boyd, J.H., \& De Nicolo, G. (2005). The theory of bank risk taking and competition revisited. The Journal of Finance, 60(3), 1329-1343.

Brooks, C. (2008). Introductory Econometrics for Finance (2nd ed.). New York: Cambridge University Press.

Carvallo, O., \& Kasman, A. (2005). Cost efficiency in the Latin American and Caribbean banking systems. Journal of International Financial Markets, Institutions and Money, 15(1), 55-72.

Casu, B., \& Girardone, C. (2006). Bank competition, concentration and efficiency in the single European market. The Manchester School, 74(4), 441-468.

Casu, B., \& Molyneux, P. (2003). A comparative study of efficiency in European banking. Applied Economics, 35(17), 1865-1876.

Casu, B., Girardone, C., \& Molyneux, P. (2004). Productivity Change in European Banking: A Comparison of Parametric and Non-Parametric Approaches. Journal of Banking and Finance, 28(10), 2521-2540.

Cohen, J.W. (1988). Statistical power analysis for the behavioural sciences (2nd ed). Hillsdale, New Jersey: Lawrence Erlbaum Associates.

DeYoung, R. (1997). A diagnostic test for the distribution-free efficiency estimator: An example using US commercial bank data. European Journal of Operational Research, 98(2), 243-249.

Fiordelisi, F., Marques-Ibanez, D., \& Molyneux, P. (2011). Efficiency and risk in European banking. Journal of Banking \& Finance, 35(5), 1315-1326.

Goodhart, C., Hofmann, B., \& Segoviano, M. (2004). Bank regulation and macroeconomic fluctuations. Oxford Review of Economic Policy, 20(4), 591-615.

Gorton, G., \& Huang, L. (2002). Banking panics and the origin of central banking (No. w9137). National Bureau of Economic Research.

Green, C., Murinde, V., \& Nicolov, I. (2004). The efficiency of foreign and domestic banks in Central and Eastern Europe: Evidence on scale and scope economies. Journal of Emerging Markets Finance, 3, 175-205.

Hasan, I., \& Marton, K. (2003). Development and Efficiency of the Banking Sector in a Transitional Economy. Journal of Banking and Finance, 27(12), 2249-2271.

Holló, D., \& Nagy, M. (2006). Bank efficiency in the enlarged European Union (No. 2006/3). MNB working papers.

International Monetary Fund. (2019). Seventh and Eighth Reviews Under the Extended Credit Facility Arrangement and Request for Waivers of Non observance of Performance Criteria. IMF Country Report No. 19/97

Isik, I., \& Hassan, M.K. (2002). Cost and profit efficiency of the Turkish banking industry: An empirical investigation. Financial Review, 37(2), 257-279.

Isshaq, Z., \& Bokpin, G.A. (2012). Expansion and efficiency in banking: Evidence from Ghana. Managerial and Decision Economics, 33(1), 19-28.

Khalib, M., Abdul-Rahman, A., \& Janor, H. (2016). Impak kecekapan kos terhadap risiko kecairan dalam institusi perbankan di Malaysia. Jurnal Pengurusan (UKM Journal of Management), 47.

Kwan, S., \& Eisenbeis, R.A. (1997). Bank risk, capitalization, and operating efficiency. Journal of Financial Services Research, 12(2), 117-131.

Lozano-Vivas, A., Pastor, J.T., \& Pastor, J.M. (2002). An efficiency comparison of European banking systems operating under different environmental conditions. Journal of Productivity Analysis, 18, 59-77.

Mamatzakis, E., Staikouras, C., \& Koutsomanoli-Filippaki, A. (2009). Bank efficiency in the new European Union member states: Is there convergence? International Review of Financial Analysis, 17, 1156-1172.

Matoušek, R., \& Taci, A. (2004). Efficiency in banking: Empirical evidence from the Czech Republic. Economics of Planning, 37(3), 225-244.

Maudos, J., Pastor, J., Perez, F., \& Quesada, J. (2002). Cost and profit efficiency in European banks. Journal of International Financial Markets Institutions and Money, 12, 33-58.

74 Journal of Applied Business and Economics Vol. 23(7) 2021 
McDonald, J.H. (2009). Handbook of biological statistics (Vol. 2). Baltimore, MD: Sparky house publishing.

McKillop, D., Glass, J., \& Ferguson, C. (2002). Investigating the Cost Performance of UK Credit Unions Using Radial and Non-Radial Efficiency Measures. Journal of Banking and Finance, 26(8), 1563-1592.

Mester, L.J. (1996). A study of bank efficiency taking into account risk-preferences. Journal of Banking \& Finance, 20(6), 1025-1045.

Ohene-Asare, K., \& Asmild, M. (2012). Banking efficiency analysis under corporate social responsibilities. International Journal of Banking, Accounting and Finance, 4(2), 146-171.

Pasiouras, F. (2008). International evidence on the impact of regulations and supervision on banks' technical efficiency: An application of two-stage data envelopment analysis. Review of Quantitative Finance and Accounting, 30, 187-223.

Pastor, J.M., \& Serrano, L. (2005). Efficiency, endogenous and exogenous credit risk in the banking systems of the Euro area. Applied Financial Economics, 15(9), 631-649.

Pessarossi, P., \& Weill, L. (2013). Do capital requirements affect bank efficiency? Evidence from China.

Podpiera, J., \& Weill, L. (2008). Bad luck or bad management? Emerging banking market experience. Journal of Financial Stability, 4(2), 135-148.

PricewaterhouseCoopers. (2018). PWC Annual Banking Survey Report vol. 1 No 1/2018.

Ramalho, E.A., Ramalho, J.J., \& Henriques, P.D. (2010). Fractional regression models for second stage DEA efficiency analyses. Journal of Productivity Analysis, 34(3), 239-255.

Said, A. (2013). Risks and efficiency in the Islamic banking systems: The case of selected Islamic banks in MENA region. International Journal of Economics and Financial Issues, 3(1).

Saka, A.N.A., Aboagye, A.Q.Q., \& Gemegah, A. (2012). Technical Efficiency of the Ghanaian Banking Industry and the Effects of the Entry of Foreign Banks. Journal of African Business, 13(3), 232243.

Sarmiento, M., \& Galán, J.E. (2017). The influence of risk-taking on bank efficiency: Evidence from Colombia. Emerging Markets Review, 32, 52-73.

Sealey, C.W., \& Lindley, J.T. (1977). Inputs, Outputs, and a Theory of Production and Cost at Depository Financial Institutions. Journal of Finance, 32(4), 1251-1266.

Securities and Exchange Commission of Ghana. (2019). SEC Public Notice No. SEC/PN/016/09/2019.

Semih Yildirim, H., \& Philippatos, G.C. (2007). Efficiency of banks: Recent evidence from the transition economies of Europe, 1993-2000. European Journal of Finance, 13(2), 123-143.

Simar, L., \& Wilson, P.W. (2007). Estimation and inference in two-stage, semi-parametric models of production processes. Journal of Econometrics, 136(1), 31-64.

Simar, L., \& Wilson, P.W. (2011). Two-stage DEA: Caveat emptor. Journal of Productivity Analysis, $36(2), 205-218$.

Srairi, S.A. (2010). Cost and profit efficiency of conventional and Islamic banks in GCC countries. Journal of Productivity Analysis, 34(1), 45-62.

Staikouras, C., \& Wood, G. (2003). Non-interest income and total income stability. Bank of England Quarterly Bulletin, 43, 332.

Tecles, P.L., \& Tabak, B.M. (2010). Determinants of bank efficiency: The case of Brazil. European Journal of Operational Research, 207(3), 1587-1598.

Wong, J., Wong, E., Fong, T., \& Choi, K.F. (2007). Testing for Collusion in the Hong Kong Banking Sector. HKMA Research Memorandum, 03/2007.

Wooldridge, J.M. (2012). Introductory econometrics: A modern approach (upper level economics titles). Southwestern College Publishing, Nashville, T ATN, 41, 673-690.

Yildrim, S., \& Philippatos, G. (2007). Efficiency of banks in transition economies of Europe, 1993-2000. European Journal of Finance, 13, 123-143. 